УДК: 373.3 .015 .3

DOI:

Володимир Сарієнко, кандидат педагогічних наук, доцент кафедри природничо-математичних дисчиилін ДВНЗ “Донбаський державний педагогічний університет” Ірина Решетова, кандидат педагогічних наук, доиент кафедри менеджменту ДВНЗ “Донбаський державний педагогічний університет”

\title{
ЛОГІКО-ДИДАКТИЧНИЙ АНАЛІЗ ПРОЦЕДУРИ ПОЯСНЕННЯ В КОНТЕКСТІ РОЗВИТКУ ТВОРЧИХ ПІЗНАВАЛЬНИХ УМІНЬ ШКОЛЯРІВ У НАВЧАННІ
}

У статті на основі логіко-структурного аналізу наукового знання розглядається сутність, зміст $і$ структура прочедури пояснення, ї̈ місце і роль в загальній системі пізнавального процесу та ї̈ проекція на навчальний процес у школі. Визначається предмет пізнавальної діяльності школярів у прочесі навчання. Розкривається зміст процуедурно-операційного способу навчання, описується технологія виконання процедури пояснення в межах зазначеного способу.

Ключові слова: структура наукового знання; навчальний процес; процедура пояснення; логічні засоби пізнання; пізнавальна діяльність; початкова освіта.

Табл. 1.Літ. 7.

Volodymyr Sariyenko, Ph.D.(Pedagogy), Associate Professor of the Natural and Mathematical Disciplines Department State Pedagogical University "Donbas State Pedagogical University" Iryna Reshetova, Ph.D.(Pedagogy), Associate Professor of the Management Department State Pedagogical University "Donbas State Pedagogical University"

\section{LOGICALANDDIDACTICANALYSIS OFTHE EXPLANATION PROCEDUREINTHE CONTEXT OFTHE DEVELOPMENTOFTHESTUDENTS'CREATIVE COGNITIVESKILLS INSTUDYING}

The relevance of the research topic outlined in the article and is determined by the urgency of the problem of developing the students' cognitive independence in learning. A large number of didactic, psychological and social studies is devoted to the solution of the questions concerning the development of creative cognitive activity of schoolchildren. At the same time, an educational practice states the fact that in spite of the large amount of scientific research in line with the above-mentioned problem, the traditional reproductive teaching method remains dominant in the practices of the school's work.

In the proposed article, the authors offer one of the solutions of this problem, based on a fundamentally new technology of organizing the educational process - a procedural and operational way of studying.

The described method is based on the structure of scientific knowledge, which consists of three components: concepts; ideas, laws, properties, statements; rules. These three elements of the scientific knowledge structure perform three functions in science: the function of description, the function of explanation, and the function of prescription, which are realized in the practice of knowledge through appropriate procedures.

In the article, the authors note that all three of these procedures in the cognitive process are closely related to each other, but at the same time, each of the cognitive procedures has certain autonomy and for research purposes is a separate subject for consideration.

The procedure of explanation in comparison with the procedures of description and prescription is the most difficult due to the variety of methods for its implementation.

On the basis of the structural analysis of the defined procedure, the article reveals its content, its own logical structure, the role and place in the overall systemic cognitive process and its projection on the learning process. The subject of the students' cognitive activity in the learning process is determined. Based on the analysis of the logical essence of laws, properties, theorems, the article describes a set of logical tools and a system of actions for performing an explanation procedure. The essence of the procedural and operational way of learning is revealed, the technology for performing the procedure of explanation within the framework of the named method is described.

The possibility of implementing the proposed method of organizing the educational process and its effectiveness are proven by experimental data.

Keywords: the structure of scientific knowledge; an educational process; an explanation procedure; logical tools of knowledge; learning activity; the primary education.

$\left\{\begin{array}{l}\text { ктуальність. Проблема формування } \\ \text { творчих пізнавальних умінь у } \\ \text { навчальній діяльності в системі різних }\end{array}\right.$

(C)

В. Сарієнко, I. Решетова, 2018 рівнів освіти займає педагогічну думку протягом багатьох століть. Бурхливий розвиток науковотехнічного прогресу, високий темп зростання 


\section{ЛОГІКО-ДИДАКТИЧНИЙ АНАЛІЗПРОЦЕДУРИПОЯСНЕННЯ В КОНТЕКСТІ РОЗВИТКУ ТВОРЧИХ ПІЗНАВАЛЬНИХ УМІНЬ ШКОЛЯРІВ У НАВЧАННІ}

об'єму інформації на сучасному етапі розвитку суспільства висунули вимогу значної активізації пошуку шляхів іiї вирішення. Протягом останніх десятиліть 3'явилася велика кількість напрацювань педагогів, психологів, соціологів в руслі іï розв'язання. Однак при цьому, на жаль, освітня практика засвідчує факт незначних зрушень у впровадженні методів творчої пізнавальної діяльності школярів у навчальний процес. Й на сьогодні у навчальній діяльності домінує репродукція.

Причиною такого становища, на наш погляд, $\epsilon$ те, що: по-перше, вчителі не володіють системою і методикою організації творчої пізнавальної діяльності. Іншими словами, не знають логіку і технологію побудови цього процесу; по-друге, домінує факт нерозуміння учнями предмету своєї пізнавальної діяльності. На передній план висувається зміст конкретних наукових фактів (конкретні теореми, означення певних понять, формулювання певних законів тощо) а не їх структурно-пізнавальна суть; по-третє, має місце невідповідність змісту навчальних засобів (підручників) цілям, структурі і методам творчої пізнавальної діяльності школярів.

Як відомо, структурними елементами наукового знання є поняття; ідеї, закони, твердження, які потребують доведення; правила. Вони виконують у науці відповідно три функції: функцію опису, функцію пояснення і функцію припису й реалізуються відповідно через процедури опису, пояснення і припису. Опис передбачає розкриття суті явища чи об'єкта, формулювання його змісту у вигляді означення. Пояснення передбачає розкриття закономірних внутрішніх і зовнішніх зв'язків у об'єкті і між об'єктами й реалізується у вигляді доведення. Припис передбачає розкриття алгоритму дій в практичному перетворенні або реалізації описаного і поясненого знання. Усі три процедури між собою тісно пов'язані і взаємо обумовлюють одна другу.

У цій структурі процедура пояснення $\epsilon$ найбільш логічно насиченою, оскільки доведення будь-якого твердження передбачає ланцюг умовиводів. Процес доведення грунтується на більш високому рівні абстракції ніж процес опису або припису і з цієї причини виникають певні складності в пізнавальному процесі школярів. Отже $з$ цих позицій розгляд змісту, структури процедури пояснення і спроектованого на цьому способу іiі впровадження у навчальний процес $\epsilon$ вельми актуальним.

Аналіз останніх досліджень і публікацій. Проблема розвитку творчої пізнавальної діяльності школярів, логіки побудови наукового та навчального знання, організації пізнавальної діяльності з метою оволодіння цим знанням досліджувалася впродовж усього періоду розвитку педагогічної думки. Значний внесок до iii дослідження був зроблений видатними педагогами як далекого минулого, так і сучасними вченими. Найбільш продуктивним уцьому процесі можна вважати другу половину минулого століття та початок нинішнього. У цей період, зокрема, М. Алексєєвим (1997р.), І. Михайловою та П. Москаленко (1991р.) досліджувалися методи і форми, структура і співвіднесеність наукового та навчального пізнання. В. Бондарем та В. Беспалько досліджувалося питання управління пізнавальною діяльністю школярів (2000 р). Питання педагогічних умов пізнавальної активності учнів досліджувалися С. Бєляєвим (2005 p). Методи наукового пізнания в шкільному навчанні досліджувалися А. Сохором (1974 р.) та Д. Вількеєвим (1975 р.). Питання закономірностей і принципів та методів навчання досліджувалися М. Даниленко (1991 р.) та Б. Коротяєвим (1979 2006 рр.). Питання організації навчально-творчої роботи школярів досліджувалися Н. Кабусь (2009 р). Питання пояснення як функції науки досліджувалися Є. Нікітіним (1979 р.). С. Пєскун досліджувала дидактичні умови творчого розвитку школярів (2006 р.). Структуру наукового знання і пізнавальної діяльності школярів у навчанні та логіко-структурний аналіз самостійної пізнавальної діяльності учнів при виконанні пізнавальних процедур, сутність процедурноопераційного способу розвитку творчого пізнання дослідив В. Сарієнко (2013 - 2017 рр.). Разом 3 названими питаннями ученими досліджувалися й низка інших питань названого напряму, зокрема, психологічні та дидактичні умови й засоби активізації пізнавальної діяльності учнів та студентів різних вікових груп, розроблялися, експериментально перевірялися та пропонувалися різні моделі розвитку творчості у навчанні, визначалися механізми, уточнювався зміст понятійного апарату.

Отже, в арсеналі педагогічної науки накопичений величезний фактичний матеріал, який розкриває досить складний характер досліджуваної проблеми і водночас висуває нові завдання, які вимагають свого розв'язання. Зазначене питання і представляється як одне 3 них.

Мета статті полягає у розкритті технології виконання процедури пояснення на основі її логікодидактичного аналізу в структурі процесу розвитку творчої пізнавальної діяльності. 


\section{ЛОГІКО-ДИДАКТИЧНИЙ АНАЛІЗПРОЦЕДУРИПОЯСНЕННЯ В КОНТЕКСТІ РОЗВИТКУ ТВОРЧИХ ПІЗНАВАЛЬНИХ УМІНЬ ШКОЛЯРІВ У НАВЧАННІ}

Виклад основного матеріалу дослідження. Зазначимо, що предметом навчання у школі $\epsilon$ наукові знання, об'єктивовані відповідно до вікових та розумових особливостей школярів. Отже, щодо структурного складу наукового знання, ми виходимо з ідеї, що будь-яке наукове знання складається $з$ трьох структурних елементів: понять; законів; принципів, правил; ідей [2]. Як ми вже зазначали, в науці вони відповідно виконують функції опису, пояснення та перетворення. Гносеологічна сутність цих структурних елементів відбиває послідовність: а) розпізнавання явищ або предметів, їхнє упорядкування й систематизацію за змістом; б) пояснення сутності об'єктів пізнання, взаємозв'язку їхніх внугрішніх складових частин і взаємодії різних об'єктів між собою, розкриття їх суттєвих зв'язків і відношень; в) перетворення об'єктів за відповідним алгоритмом 3 одного стану в інший. Сукупність цих елементів утворює теорію, а сукупність теорій - навчальний предмет. У цьому разі наукове знання та його структурні елементи й виступають як предмет пізнавальной діяльності [4]. У процесі пізнавальної діяльності учень засвоює адаптоване для шкільного віку наукове знання, і в цьому разі знання виступає як результат його пізнавальної діяльності.

Опис, пояснення й припис між собою тісно пов'язані. В описі завжди присутні елементи пояснення й припису, а в поясненні використовуються процедури, притаманні опису й припису [4]. Тобто, не впливаючи на об'єкт і не перетворюючи його, суб'єкт не може зрозуміти його походження й залишається на рівні простого опису. Зрозуміти сутність об' єкта - значить зуміти його відтворити, побудувати. Звідси сутність пізнання характеризується двома моментами відтворенням і створенням, репродукцією й творчістю.

Діалектична єдність процедур пізнання передбачає й певну різницю між ними: кожна 3 них має свою особливість і специфіку, тому має право на свою відносну самостійність. Виділення ж їх у самостійні елементи здійснюється дослідниками умовно 3 дослідними цілями. Виділивши їх, можна навчити учнів на конкретному матеріалі методам опису, пояснення й припису. Різниця цих методів і способів визначається специфікою й особливостями кожної 3 процедур [6].

Отже, звернемося до змісту названих процедур, й у першу чергу до процедури пояснення, як ключову, з певним ухилом на зазначену тему.

Як зазначає $Є$. Нікітін в роботі "Пояснення функція науки" [5], пояснення передбачає 3'ясування сутності відношень між об'єктами або частинами об'єкта. У процесі пояснення відбувається проникнення в логіку поточних зв'язків, які можуть бути невидимими, але розумово передбачуваними. Одне 3 ключових питань функції пояснення - “Чому...?". Модифікації цього запитання: “Чим це викликано?”, “Що є причиною такого-то явища (такого-то стану)?”. Отже, якесь явище, стан, відношення $\epsilon$ наслідком певної умови. Таким чином, в основі пояснення лежать причиннонаслідкові зв”язки, які мають мовну форму “Якщо ..., то ...”. Кожне таке твердження має імплікативну основу i, за правилами математичної логіки, може мати істинне або хибне значення. Математична логіка розглядає доведення як логічну форму встановлення істинності певного твердження на основі системи інших тверджень, які є очевидними (або аксіоматичними) або істинність яких уже доведена. У доведенні математична логіка виділяє три структурні складові: тезу (твердження, істинність якого треба довести); аргументи (твердження, за допомогою яких доводиться істинність тези); демонстрацію (спосіб логічного виведення тези з аргументів).

3 аналізу структури пояснення випливає процедура доведення істинності або хибності твердження щодо відношень та зв'язків між об’єктами та явищами. Математична логіка розглядає декілька методів доведення, найбільш уживаними 3 яких у старшій школі можна назвати: синтетичний, аналітичний, метод від супротивного, метод повної індукції, метод дедуктивних доведень, метод математичної індукції та інші. Застосування методів пов'язане зі способами міркування - дедукцією та індукцією. Ознайомлюють учнів із тим чи іншим методом доведення та застосовують їх у старших класах загальноосвітньої школи "обережно” і поступово. Однак, на нашу думку, певну пропедевтичну роботу в цьому напрямку слід проводити вже в середній ланці освіти, а можна починати навіть із початкових класів. Сутність методів доведення описана в багатьох працях представників фізико-математичної науки, методистами і навіть філософами. Педагогіка також широко використовує їх надбання, але 3 позицій використання у навчальній сфері діяльності.

Проблема доведень у навчанні шкільних предметів, і в першу чергу математики та фізики, турбує і вчителів-практиків, і методистівнауковців. Спостереження науковців [1], [3], [7], в томучислі й наші, свідчать, що в нинішній шкільній практиці при вивченні пояснювального матеріалу 


\section{ЛОГІКО-ДИДАКТИЧНИЙ АНАЛІЗПРОЦЕДУРИПОЯСНЕННЯ В КОНТЕКСТІ РОЗВИТКУ ТВОРЧИХ ПІЗНАВАЛЬНИХУМІНЬ ШКОЛЯРІВ У НАВЧАННІ}

превалює репродуктивний метод: учитель сам викладає навчальний матеріал з епізодичними зверненнями до учнів. На запит “Чому це так?" домінує відповідь, що учні в більшості самі неспроможні побудувати ланцюг умовиводів, і що ці вміння можуть бути розвинуті тільки завдяки накопиченню вагомого досвіду. На запитання: “А чи знають учні структуру пояснення?”, як правило, чуємо відповідь: “Ні!”. Практика ж доводить, що відтворення та заучування готових доведень не дає достатньо позитивних результатів. У той же час учні значно швидше оволодівають уміннями доводити твердження в процесі цілеспрямованого, спеціального навчання процедурі пояснення.

Одним із провідних логічних засобів виконання доведення є порівняння. Воно здійснюється в процесі спостереження за станом і динамікою змін об'єкта або явища, викликаних певними умовами [7]. Суть порівняння тут полягає у наступному: фіксується певний стан об'єкта або явища, потім створюються певні умови й знов фіксується його стан. Потім умови можуть знов змінюватися, і знов фіксується стан. І так певну кількість разів відповідно до змісту завдання й змісту об'єкта. Зафіксовані стани об'єкта порівнюються. Унаслідок порівняння встановлюється, як зміна умови вплинула на стан об'єкта. Так відбувається заглиблення в сутність відношень між умовами існування об'єкта і його станом, тобто виявлення впливу умов на стан об'єкта. Наприклад, у комбінаториці при виведенні формули числа перестановок $3 n$ елементів розглядається умова вибору першого елемента перестановки. Коли кількість варіантів вибору встановлено, умова змінюється й розглядається кількість варіантів вибору другого елемента, а з ним і кількість варіантів вибору пари 3 першого та другого елементів. Після цього умова знов змінюється, встановлюється кількість варіантів вибору третього елементу, а з ним і кількість варіантів вибору трійок. I так до тих пір, поки не будуть перебрані всі елементи. Тим чином доводиться, що кількість перестановок із $n$ елементів обчислюється за формулою $P_{n}=n$ !.

$\mathrm{У}$ природничо-математичних дисциплінах причинно-наслідкові зв'язки виявляються в найбільш чистому вигляді. Формулювання теорем, властивостей, законів найчастіше висловлюються у формі складнопідрядного речення, в якому в чистому вигляді виявляються причиннонаслідкові зв'язки. Форма: “Якщо ..., то...”. Перше речення (умова) - причина, друге (висновок) - наслідок. Причина обумовлює наслідок. Часто в певних межах ця причинно- наслідкова форма утворює цілий ланцюг: певна умова щодо якогось об'єкта або явища тягне за собою певний наслідок, а він, у свою чергу, стає причиною нового наслідку. Наприклад, “Якщо просторова фігура $є$ прямий прямокутний паралелепіпед, то в основі їі лежить прямокутник”; $\Rightarrow$ “Якщо в основі фігури прямокутник, то квадрат його діагоналі дорівнює сумі квадратів сторін основи”; $\Rightarrow$ “Якщо квадрат його діагоналі основи дорівнює сумі квадратів сторін основи, то квадрат діагоналі паралелепіпеда дорівнює сумі квадратів усіх його трьох вимірів". Аналогічні ланцюжки складають основу практично всіх явищ.

Разом 3 тим причина і наслідок можуть мінятися місцями, тобто як умова впливає на наслідок, так і наслідок може впливати на умову. У математиці це проявляється в обернених теоремах.

Знання про причинно-наслідкові відношення дають можливість проникати в суть досліджуваного об'єкта, виконують прогностичну функцію, тобто надають можливість передбачати образ майбутнього результату.

Важливим етапом у процедурі пояснення є формулювання законів, принципів, теорем, властивостей, тобто усіх зв'язків і відношень, які в них відображені. Пояснення подаються за допомогою чітких і коротких тверджень і здійснюються системою умовиводів або логікоматематичних доведень, які розкривають й обумовлюють закономірний характер їхніх зв'язків і відношень.

Усі зазначені категорії мають одну структуру - причинно-наслідковий зв'язок. Але досліджуючи їх формулювання, ми змушені наголосити, що часто в підручниках вони подаються у вигляді, в якому структура “Якщо..., то...” завуальована певним мовним оборотом, представлена в неявному вигляді. Особливо така форма $є$ характерною для фізики. Наприклад, закон Кулона щодо взаємодії електричних зарядів. Він у підручнику представлений так: “Два точкових заряди $q_{1}$ i $q_{2}$, які знаходяться в заданому середовищі на відстані $r$ один від одного, взаємодіють із силою $F$, прямо пропорційною добутку цих зарядів, і обернено пропорційною квадрату відстані між ними".

Як бачимо, в законі відсутня пряма схема “Якщо..., то...”. Отже, першою перед учнями стоїть задача виділити в реченні елементи, які належать до умов, і ті, що належать до висновків. Для усвідомлення суті закону цей крок є одним із головних. Логічний аналіз твердження підказує, що його треба починати 3 виявлення: а) який об’єкт досліджується; б) у якому стані він 


\section{ЛОГІКО-ДИДАКТИЧНИЙ АНАЛЗ ПРОЦЕДУРИПОЯСНЕННЯ В КОНТЕКСТІ РОЗВИТКУ ТВОРЧИХ ПІЗНАВАЛЬНИХ УМІНЬ ШКОЛЯРІВ У НАВЧАННІ}

знаходиться; в) яке перетворення 3 ним здійснюється або які інші об'єкти на нього впливають; г) які причини викликають перетворення; д) які результати (наслідки) заподіяного впливу або перетворення; е) як це фіксується в символічній формі.

Проаналізуємо наведений приклад. Система визначення умов і висновку тут виглядає так:

1. Із якими об'єктами здійснюється дослідження? Відповідь: із двома зарядами.

2. У якому стані вони знаходяться? Відповідь: a) вони знаходяться в одному середовищі та б) вони знаходяться на відстані $r$ один від одного.

3. Яка взаємодія встановлена між ними? Відповідь: вони взаємодіють із певною силою $F$.

4. Як вона відноситься до цих зарядів? Відповідь: вона прямо пропорційна їх добутку.

5. А як вона відноситься до відстані між зарядами? Відповідь: вона обернено пропорційна квадрату відстані між ними.

Отже, що треба мати, щоб обчислити силу $F$ ? Треба два заряди помістити в певне середовище на певній відстані $r$.

Звідси: 1. "Що є причиною взаємодії двох зарядів?” Відповідь: “Поміщення двох зарядів у певне середовище на відстані $r$ один від одного”.

2. “Що є наслідком такої дії?” Відповідь: “Вони взаємодіють із силою $F$, яка за обчисленням $\epsilon$ прямо пропорційною добутку цих зарядів, i обернено пропорційною квадрату відстані між ними”.

Отже, у формі причинно-наслідкового зв'язку закон Кулона має бути сформульований так: “Якщо два заряди помістити в певне середовище на відстані $r$ один від одного, то вони взаємодіють iз силою $F$, прямо пропорційною добутку цих зарядів і обернено пропорційною квадрату відстані між ними".

3 наведеного прикладу випливає висновок, що умова (причина) у формулюванні законів складається 3 необхідних факторів (ознак), а висновок (наслідок ) - 3 достатніх.

Цей висновок дуже важливий, оскільки він дає ключ до перетворення неявного формулювання у явну форму “Якщо..., то...”. Тобто учням необхідно визначити необхідні й достатні умови взаємодії двох об'єктів, а потім записати їх за схемою: “Якщо... (необхідні умови), то... (достатні) умови".

У математиці також багато формулювань теорем, властивостей, поданих не уформі причиннонаслідкових зв'язків, тобто у неявній формі, але їх менше й вони легше переводяться в зазначену явну форму. Та технологія перетворення формулювання 3 неявної форми в явну така сама, як і у фізиці.
Аналіз суті законів, принципів, теорем, тобто тих структурних елементів наукового знання, які виконують функцію пояснення, дає можливість визначити таку систему дій для виконання цієї процедури. Їх набір складається $з$ таких дій:

1. Спостереження предметів або явищ (або їх структурних елементів, якщо досліджується один об'єкт).

2. Пошук зв'язків і відношень між ними, визначення серед них істотних, усталених, прямих й обернених, необхідних і достатніх.

3. Формулювання словесних положень, у яких відображаються знайдені зв'язки й відношення.

4. Кодування основних понять і відношень у символічну форму.

5. Доведення сформульованого твердження.

Виконання цих дій вимагає у дослідника (учня) використання таких логічних засобів:

а) поняття причини й наслідку;

б) ознак схожості й відмінності;

в) ознак необхідних і достатніх, істотних і неістотних;

г) понять закону, принципу, теореми, ідеї, властивості;

д) операцію порівняння;

е) правило формулювання законів, ідей, теорем, принципів, властивостей;

є) способи доведення тверджень, висловлених уних;

ж) уміння оперувати цими поняттями, правилами, способами.

3 аналізупроцедури пояснення можна виділити систему дій, які треба виконати, щоб довести твердження безвідносно до виду формулювання: 1) спостереження. У процесі спостереження учень (дослідник) визначає множину об'єктів, елементом якої є об' єкт, що вивчається; 2) пошук зв'язків та відношень між даними та шуканим, виділення серед них стійких, прямих та обернених, безпосередніх та опосередкованих; 3) формулювання у словесній формі властивостей, законів, теорем, у яких відображаються знайдені зв'язки та відношення; 4) кодування словесних положень; 5) доведення визначених тверджень; 6) формулювання висновку

Виконання цих дій вимагає певних розумових операцій, які передбачають наявність певного логіко-пізнавального інструментарію, тобто логічних засобів, необхідних для виконання процедури пояснення. Змістом такого логічного інструментарію для цієї процедури є: порівняння, ознаки родові та видові, ознаки істотні й неістотні, необхідні й достатні, способи визначення виду означення, правило його формулювання, логічні уміння й навички оперування даним логічним поняттями, операціями, правилами [6]. 


\section{ЛОГІКО-ДИДАКТИЧНИЙ АНАЛІЗПРОЦЕДУРИПОЯСНЕННЯ В КОНТЕКСТІ РОЗВИТКУ ТВОРЧИХ ПІЗНАВАЛЬНИХ УМІНЬ ШКОЛЯРІВ У НАВЧАННІ}

Знання про причинно-наслідкові зв'язки забезпечує проникнення учня в сутність явища чи предмета, який вивчається, дає можливість передбачити певною мірою результат діяльності, що у свою чергу забезпечує успішне оволодіння учнем навчального предмету.

Важливим етапом у виконанні процедури пояснення $\epsilon$ формулювання у словесній формі виявлених зв'язків і відношень і гіпотетичних висновків. Ця форма має єдину основу- причиннонаслідковий зв'язок, а відповідно і схожу структуру. Отже, щоб сформулювати закон, властивість, теорему необхідно встановити зв'язок між наявністю визначених умов i гіпотетичним результатом. Зняття протиріччя між умовою і результатом здійснюється шляхом доведення.

Доведення - це визначення у висловленому судженні взаємозв'язків між вихідними даними даних між собою, потім шляхом певного комбінування цих даних та їх зв'язків отримання ланцюга проміжних результатів і так до тих пір, поки не здійсниться вихід на підсумковий прогнозований результат.

Верифікація запропонованого способу оволодіння учнями процедурою пояснення здійснювалася експериментальним дослідженням, проведеним у випускних класах загальноосвітніх шкіл на предметах природничо-математичного циклу протягом 3-х років. Підсумковий результат представлений табл. 1. операційного, що відкриває нові перспективи в організації творчої пізнавальної діяльності учнів.

Із наведеного аналізу випливає технологія навчання поясненню відношень між об'єктами пізнання. По-перше, це ознайомлення учнів сутністю відношень і зв'язків між об'єктами. Подруге, формування в учнів навичок формулювання визначених відношень та зв'язків. По-третє, ознайомлення учнів з системою пізнавальних дій, які слід виконати, щоб пояснити ці відношення і довести їх закономірний характер. По-четверте, це ознайомлення учнів з логічними засобами виконання цієї системи дій. По-п’яте, за допомогою системи спеціальних вправ вироблення в учнів уміння виконувати визначені діï за допомогою зазначеного логічного інструментарію. Експериментальні дані свідчать, що для цього достатньо 3 - 4 уроки. Надалі ці вміння закріплюються в процесі поточної навчальної роботи 3 вивчення програмного матеріалу.

Перспективи подальшого дослідження. Упровадження процедурно-операційного підходу до оволодіння науковими знаннями процесі навчальної діяльності висуває нові завдання перед педагогічною наукою. Оволодіння учнями технологіями виконання пізнавальних процедур в загальному вигляді повинне впроваджуватись на всіх рівнях шкільного навчання. В той же час методичні підходи в різних вікових групах значно різняться відповідно до рівня розвитку логічного

Таблиця 1.

Порівняльний аналіз результатів виконання завдання процедурою пояснення учнями експериментальної і контрольної груп

\begin{tabular}{|c|c|c|c|c|}
\hline 11 класи & 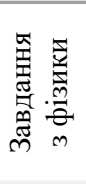 & 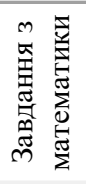 & 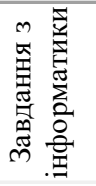 & 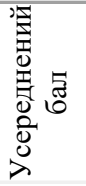 \\
\hline \multicolumn{5}{|c|}{ Експериментальна група (107 учнів) } \\
\hline Коефіцієнт виконання завдання (валідність) & 0,80 & 0,88 & 0,79 & 0,82 \\
\hline \multicolumn{5}{|c|}{ Контрольна група (98 учнів) } \\
\hline Коефіцієнт виконання завдання (валідність) & 0,20 & 0,33 & 0,24 & 0,26 \\
\hline
\end{tabular}

Порівняльний аналіз результатів виконання завдання на пояснення учнями експериментальної і контрольної груп засвідчує доволі значне випередження перших порівняно 3 другими - у 3,15 рази, що свідчить про ефективність запропонованого способу формування самостійних пізнавальних умінь у виконанні процедури пояснення.

Висновок. Отже, аналіз структури наукового знання дає ключ до принципово нової організації навчального процесу, а саме, процедурно- мислення. Тому в плані наступних досліджень набуває потреби дослідження щодо особливостей впровадження процедурно-операційного способу в початковій, середній і старшій віковій ланках.

\section{ЛІТЕРАТУРА}

1. Бондар В. І. Дидактика / Володимир Бондар. - К.: Либідь, 2005. - 264 с.

2. Вилькеев Д. В. Методы научного познания в школьном обучении / Д. В. Вилькеев. - Казань: Таткнигиздат, 1975. - 160 с. 
3. Кабусь Н.Д. Організація навчально-творчої діяльності старшокласників загальноосвітніх навчальних закладів: дис. ... канд. пед. наук: 13.00.09 /. Кабусь Наталія Дмитріївна. - Х., 2009. $-216 \mathrm{c}$.

4. Коротяєв Б. І. Методи навчально-пізнавальної діяльності учнів / Б. І. Коротяев // Избр. пед.соч.: в 3 т./Б. І. Коротяєв. - Луганск, 2006. - Т.1. С. 24-206.

5. Никитин Е. П. Объяснение - функция науки / Е. П. Никитин. - М.: Наука, 1979. - 280 с.

6. Сарієнко В. В. Структурування знань як необхідна умова навчання учнів творчій пізнавальній діяльності / В. В. Сарієнко // Науковий часопис НПУ імені М.П.Драгоманова. Серія 17: Теорія і практика навчання та виховання. - К., 2010. - Вип. 15. - С. 150-157.

7. Склярова I. О. Педагогічне керівництво навчально-пізнавальною діяльністю старшокласників загальноосвітньої школи упроцесі вивчення фізикоматематичних предметів: дис. ... канд. пед. наук: 13.00.09 / Склярова Ірина Олександрівна. - К., 2008. -223 c.

\section{REFERENCES:}

1. Bondar, V. I. (2005). Dydaktyka [Dydaktyka]. Kyiv: Lybid Publ., 264 p. [in Ukrainian].

2. Vylkeev, D. V. (1975). Metody nauchnoho poznanyia $v$ shkolnom obuchenyy [Methods of scientific knowledge in schooling]. Kazan: Tatknigizdat Publ., 160 p. [in Russian].
3. Kabus, N. D. (2009).Orhanizatsiia navchalnotvorchoi diialnosti starshoklasnykiv zahalnoosvitnikh navchalnykh zakladiv [Organization of primary and creative seniority of senior pupils in general educational institutions]. Candidate's thesis. Kharkiv, 216 p. [in Ukrainian].

4. Korotiaiev, B. I. (2006). Metody navchalnopiznavalnoi diialnosti uchniv [Methods of educational and cognitive activity of students]. Lugansk: Alma-mater Publ., Vol.1, pp. 24 -206. [in Ukrainian].

5. Nykytyn, E. P. (1979). Obiasnenye funktsyia nauky [Explanation is a function of science]. Moskov: Science Publ., 280 p. [in Russian].

6. Sarienko, V. V. (2010). Strukturuvannia znan yak neobkhidna umova navchannia uchniv tvorchii piznavalnii diialnosti [Structuring knowledge as a necessary condition for teaching students creative cognitive activity. Theory and Practice of Teaching and Upbringing]. Scientific journal of the M.P. Drahomanov NPU Publ., Vol. 15, pp. 150-157. [in Ukrainian].

7. Skliarova, I. O. (2008). Pedahohichne kerivnytstvo navchalno-piznavalnoiu diialnistiu starshoklasnykiv zahalnoosvitnoi shkoly u protsesi vyvchennia fizyko-matematychnykh predmetiv [Pedagogical leadership of educational and cognitive activity of senior pupils of a secondary school in the process of studying physical and mathematical subjects]. Candidate's thesis. Kyiv, 223 p. [in Ukrainian].

Стаття надійшла до редакції 15.11.2018

\section{G58080}

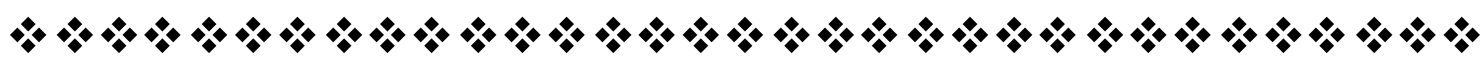

"Фоқаз істинності будв яқого поқлиқання - любов до важкої роботи, якої воно вимагає".

Вернон Яомақс Сміт америқанський еқономіст

“Найважливіше завдання циивілізащї̈-навчити людину мислити”.

"Найбільша помилқа в тому, що ми швидқо здаємося. Іноді, щоботримати бажане, треба просто спробувати ще один раз”.

“Все приходить до того, хто працює і вміє чекати”.

TТомас Едісон всесвітньо відомий американсьқий винахідник

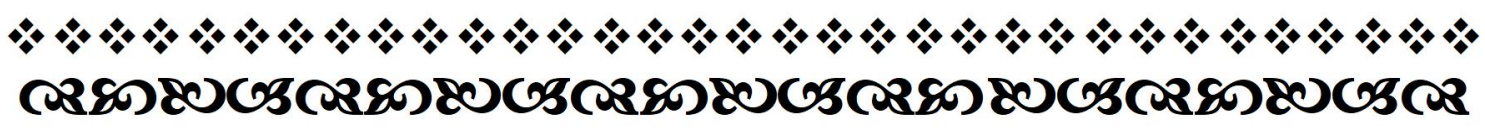

Молодь і ринок №12 (167), 2018 